\title{
Selective serotonin reuptake inhibitor use and mortality, postoperative complications, and quality of care in hip fracture patients: a Danish nationwide cohort study
}

This article was published in the following Dove Press journal:

Clinical Epidemiology

\author{
Stine Bakkensen Bruun' \\ Irene Petersen ${ }^{1,2}$ \\ Nickolaj Risbo Kristensen' \\ Deirdre Cronin-Fenton' \\ Alma Becic Pedersen' \\ 'Department of Clinical Epidemiology, \\ Aarhus University Hospital, Aarhus, \\ Denmark; ${ }^{2}$ Department of Primary \\ Care and Population Health, \\ University College London, London, \\ UK
}

\begin{abstract}
Purpose: To examine the association between selective serotonin reuptake inhibitor (SSRI) use and mortality, postoperative complications, and quality of in-hospital care in hip fracture patients.

Patients and methods: The study was a nationwide cohort study based on individual-level linked, prospectively collected data from Danish population-based national registries covering all hospitals in Denmark. The health care system in Denmark is tax-funded, and all citizens have equal access to health care services. We included patients with first-time hospitalization due to hip fracture undergoing surgery from 2006-2016. We estimated the risk of 30-day mortality, any unplanned readmission, any reoperation, specific postoperative complications including cardiovascular events and major bleeding, and quality of in-hospital care using Cox and Poisson regression analyses comparing current and former SSRI users with non-users.
\end{abstract}

Results: In 68,487 hip fracture patients, 13,272 (19\%) were current SSRI users, 2,777 (4\%) were former SSRI users, and 52,438 (77\%) were SSRI non-users. The 30-day mortality risk was $13 \%$ in current SSRI users (HR 1.16, 1.10-1.21) and 12\% in former (HR 1.15, 1.04-1.27) compared with $10 \%$ in non-users. The HR for any unplanned readmission was $1.11(1.02-1.20)$ in current and $1.13(1.01-1.27)$ in former SSRI users and for any reoperation 1.21 (1.11-1.31) in current and $1.04(0.84-1.28)$ in former SSRI users compared with non-users. The risk of venous thromboembolism, myocardial infarction, stroke, and bleeding were similar irrespective of SSRI use. No association between current and former SSRI use and quality of in-hospital care was found.

Conclusion: In patients undergoing hip fracture surgery, 30-day mortality and overall readmission risk were elevated in both current and former SSRI users compared with non-users. Those currently using SSRI had a 26\% increased reoperation risk compared with non-users. However, SSRI use was not associated with increased risk of other postoperative complications and lower quality of in-hospital care. A limitation of this study was the inability to control for potential confounding of social deprivation.

Keywords: cohort studies, hip fracture, mortality, postoperative complications, quality of care, selective serotonin reuptake inhibitors

\section{Introduction}

Hip fracture is a frequent surgical procedure among the elderly. ${ }^{1}$ It correlates with high medical costs and health care utilization ${ }^{2}$ and confers increased risk of mortality. ${ }^{3}$ Thirty-day mortality in elderly surgically treated hip fracture patients is $10 \%$ and
Correspondence: Stine Bakkensen Bruun Department of Clinical Epidemiology, Aarhus University Hospital, Olof Palmes Allé 43-45, 8200 Aarhus N, Denmark

Tel +4587167212

Fax +4587167215

Email stinebb@post.au.dk 
increases to $30 \%$ within 1 year. ${ }^{4}$ Patients who receive the recommended pre- and postoperative in-hospital care such as pain assessment, nutritional risk assessment, osteoporosis prophylaxis, and basic mobility assessment at admission and discharge may have a lower mortality risk compared with those who do not. ${ }^{5}$ Additionally, high mortality is linked to the occurrence of postoperative complications, which affect $\sim 20 \%$ of elderly hip fracture patients. ${ }^{5,6}$ The most common postoperative complication is infection. ${ }^{4}$ However, patients can experience venous thromboembolism (VTE), myocardial infarction (MI), stroke, and gastrointestinal bleeding as well.,

Elderly hip fracture patients are often multimorbid and receive multiple prescription medications including selective serotonin reuptake inhibitors (SSRIs). ${ }^{8}$ SSRIs are prescribed to $10 \%$ of Danish elderly aged 65 years or older. ${ }^{9}$ The most common indications for SSRI prescribing are depression and anxiety. ${ }^{10}$ In general, SSRI use appears to increase the risk of mortality, new cardiovascular events, and postoperative bleeding. ${ }^{6,11}$ Previous studies among patients undergoing major surgery, including orthopedic surgeries, reported higher risk of mortality, readmission, and blood transfusion in those using SSRIs perioperatively. ${ }^{12,13}$ However, a study including orthopedic patients showed no evidence that SSRI use increased the risk of receiving a blood transfusion. ${ }^{14}$ Thus, existing literature examining the effect of SSRI use on surgery outcome is somewhat inconclusive. The impact of preadmission SSRI use on mortality, postoperative complications, and quality of inhospital care among elderly and fragile hip fracture patients has not been reported previously. Therefore, we conducted a nationwide, prospective cohort study examining whether preadmission SSRI use is associated with adverse outcomes in hip fracture surgery patients.

\section{Ethics approval}

Ethical approval was not required according to the Danish Act on Research Ethics Review of Health Research Projects due to the register-based nature of the study. The study was approved by the Danish Data Protection Agency (record number: 1-16-02-467-15).

\section{Patients and methods}

\section{Setting and design}

The study is a nationwide cohort study using prospectively collected data from Danish medical registries covering all Danish citizens; approximately 5.7 million people. ${ }^{15}$ The health care system in Denmark is tax-funded, and all citizens have equal access to health care services.

\section{Data sources}

The Danish Multidisciplinary Hip Fracture Registry ${ }^{16}$ has routinely registered comprehensive clinical data on all patients aged 65 years or older with first-time hip fracture admitted to any orthopedic department in Denmark since 2004. Data include detailed pre- and postoperative data, as well as data on quality of in-hospital care represented by process-performance measures. The Danish Civil Registration System ${ }^{17}$ established in 1968 holds data on date of birth, vital status, and migration on all individuals in Denmark. Every citizen has a unique civil personal registration number, which allows for individual-level linkage across all Danish registries. The Danish National Patient Registry ${ }^{18}$ contains data on civil personal registration number, hospital admission and discharge diagnosis codes, and diagnostic and surgical procedure codes from all Danish somatic hospitals since 1977. Diagnoses were coded using the ICD-8 until the end of 1993 and ICD-10 thereafter. The Danish National Database of Reimbursed Prescriptions ${ }^{19}$ tracks reimbursed medicine dispensing at all community pharmacies and hospital-based outpatient pharmacies in Denmark since 2004. The database holds data on civil personal registration number, Anatomical Therapeutic Chemical code, redemption date, item quantity, pack size, defined daily dose, dose form, and generic substitution done at pharmacy.

\section{Participants}

Patients aged 65 years or older undergoing surgical treatment for hip fracture between 2004 and 2016 were identified in the Danish Multidisciplinary Hip Fracture Registry. The study period was subsequently restricted to patients registered between January 1, 2006, and December 31, 2016, to ensure at least 2 years prescription history. Patients with missing data on operation delay $(n=119)$ were excluded. In total, 68,487 first-time hip fracture patients who received surgery from 2006-2016 were available for analyses.

\section{Variables \\ Exposure}

All redeemed prescriptions for SSRIs 1 year before hip fracture surgery were identified in the Danish National Database of Reimbursed Prescriptions. Patients were classified according to SSRI use. Current SSRI users redeemed at least one prescription within 90 days, former users redeemed 
one prescription between 91 and 365 days, and non-users redeemed no prescriptions within 365 days before hip fracture surgery.

\section{Outcomes}

Several outcomes occurring after hip fracture surgery were examined separately. First, all-cause 30-day mortality was ascertained from the Civil Registration System. Second, postoperative complications were ascertained from the Danish National Patient Registry. The following postoperative complications were examined: 1) any unplanned readmission, 2) any reoperation, 3) cardiovascular events including VTE, MI, and stroke, and 4) major bleeding defined as intracranial bleeding, gastrointestinal bleeding, or urinary/lung bleeding within 30 days of surgery. Third, quality of in-hospital care represented by process-performance measures ${ }^{20}$ including preoperative optimization, operation delay, mobilization within 24 hours postoperatively, basic mobility assessment at admission and discharge, nutritional risk assessment, osteoporosis prophylaxis, and future fall prophylaxis were obtained from the Danish Multidisciplinary Hip Fracture Registry.

\section{Covariates}

Operation year, housing, BMI, fracture type, operation type, and operation delay information was assessed from the Danish Multidisciplinary Hip Fracture Registry. Four categories comprising housing information were created: own accommodation, residential institution, homeless, and unknown. Likewise, four categories based on BMI values were created: underweight (BMI $<18.5 \mathrm{~kg} / \mathrm{m}^{2}$ ), normal weight (BMI $\geq 18.5<25 \mathrm{~kg} / \mathrm{m}^{2}$ ), overweight or obese (BMI $\geq 25 \mathrm{~kg} / \mathrm{m}^{2}$ ), and unknown. Age, gender, and marital status were obtained from the Danish Civil Registration System. Comorbidities were identified using the Danish National Patient Registry. Overall comorbidity was summarized according to the original Charlson Comorbidity Index (CCI) score. The CCI was categorized as low (score 0), medium (score 1-2), and high (score $\geq 3$ ) comorbidity score, slightly modified compared with the original $\mathrm{CCI} .{ }^{21}$ The following medications were assessed from the Danish National Database of Reimbursed Prescriptions: non-steroidal anti-inflammatory drugs, corticosteroids, anticoagulants, statins, non-SSRI antidepressants, and antipsychotics. Use of each medication was defined as follows: current users redeemed one prescription within 90 days, former users redeemed one prescription between 91 and 365 days, and non-users redeemed no prescriptions within 365 days before hip fracture surgery. All codes defining study variables are available in Tables S1-S3.

\section{Statistical methods \\ Main analyses}

Patient characteristics were tabulated according to SSRI use. All patients were followed from operation date to death, any unplanned readmission, any reoperation, cardiovascular event, bleeding event, or up to 30 days. Kaplan-Meier curves of the three SSRI exposure groups were plotted depicting the absolute mortality risk over time. The cumulative incidence of postoperative complications was estimated treating death as a competing risk. Crude and adjusted HRs with 95\% CIs of death and postoperative complications within 30 days were estimated using Cox regression analysis comparing current and former SSRI users with non-users. The mortality model was evaluated for effect modification by age and gender. Readmission outcome data were only available for patients operated on from January 1, 2011 onward, thus readmission analyses were restricted to patients operated on between January 1, 2011 and December 31, 2016. RRs of quality of in-hospital care were estimated using Poisson regression analysis. The process-performance measures representing quality of in-hospital care were introduced in the Danish Multidisciplinary Hip Fracture Registry at various times. Therefore, the analyses regarding the quality of in-hospital care were performed only in hip fracture patients operated on between January 1, 2015 and December 31, 2016. Potential confounder assessment was done using a directed acyclic graph (Figure S1). ${ }^{22}$ All adjusted analyses accounted for age, gender, marital status, operation year, comorbidities, other medication, and clustering by unit setting.

\section{Sensitivity analysis}

Two sensitivity analyses were performed to test the robustness of the results. First, missing BMI values were imputed using multiple imputation (Supplementary materials). ${ }^{23}$ Missing housing data were not imputed due to lack of predictors. Second, the exposure definition was changed to address potential compliance problems; current SSRI users redeemed two prescriptions within 2 years, of which one prescription was redeemed within 8 months before hip fracture, former users redeemed two prescriptions between 8 months and 2 years, and non-users redeemed one or no prescriptions within 2 years before hip fracture. The mortality analysis was repeated including BMI in the Cox regression model and employing a new exposure definition. Cox and Poisson regression analyses were performed using Stata 14 for Windows (StataCorp LP, College Station, TX, USA). The Kaplan-Meyer plot was produced using R for Windows 3.4.2 (The R Foundation for Statistical Computing, Vienna, Austria). 


\section{Results}

\section{Patient characteristics}

We identified 68,487 first-time hip fracture patients between 2006 and 2016. Of these, 13,272 (19\%) were current SSRI users, 2,777 (4\%) former, and 52,438 (77\%) non-users. Table 1 presents the patient characteristics according to SSRI use. The median patient age was 84 years in current users (IQR $78-89$ years) and 83 years in former users (IQR 77-88 years) and non-users (IQR 77-89 years). The current and former SSRI users had higher overall comorbidity than non-users, as well as higher prevalence of cerebrovascular disease, dementia, use of non-SSRI antidepressants, and antipsychotics. Current SSRI users had a higher prevalence of anticoagulant use than both former users and non-users (Table 1).

In total, 13,295 patients (19\%) were missing BMI data and 30,285 (44\%) patients were missing housing data. From the available housing data, we observed that SSRI non-users (25,537 [49\%]) more often lived in their own accommodation compared with current $(4,412$ [33\%]) and former $(1,126$ [41\%]) users. However, there was no difference in BMI distribution between the exposure groups (Table 1).

\section{Mortality}

Overall, 7,295 hip fracture patients died within the first 30 days following hip fracture surgery. Mortality was higher in current (13\%) and former (12\%) users compared with non-users (10\%) (Figure 1 and Table 2). Compared with nonusers, the adjusted HR was $1.16(1.10-1.21)$ in current users and 1.15 (1.04-1.27) in former users (Table 2). We found no effect modification by age and gender of the relation between SSRI use and mortality.

\section{Readmission and reoperation}

Table 2 shows cumulative incidences and HRs of any unplanned readmission and any reoperation within 30 days postoperatively. In total, 6,208 of 36,356 were readmitted and 2,327 of 68,487 re-operated within 30 days after surgery. Both current (HR 1.11, 1.02-1.20) and former users (HR 1.13, 1.01-1.27) had a higher readmission risk compared with non-users. Current SSRI users had a higher reoperation risk (HR 1.21, 1.11-1.31) compared with non-users while there was no difference between former users (HR 1.04, 0.84-1.28) and non-users.

\section{Other postoperative complications}

During the first 30 days following hip fracture surgery, 573 patients experienced VTE, $546 \mathrm{MI}, 863$ stroke, and 1,011 major bleeding. Table 2 shows cumulative incidences and HRs of the individual complications. Current SSRI users had a similar risk of VTE (HR 0.89, 0.67-1.17), MI (HR 1.03, 0.81-1.30), stroke (HR 0.93, 0.80-1.09), and bleeding (HR $1.06,0.89-1.28)$ as non-users. Likewise, former SSRI users had a similar risk of VTE (HR 0.93, 0.64-1.35), MI (HR $0.89,0.57-1.40$ ), stroke (HR 0.67, 0.44-1.01), and bleeding (HR 1.06, 0.69-1.64) as non-users.

\section{Quality of in-hospital care}

The analyses included 11,363 patients operated on during 2015-2016. Figure 2 shows a marginally higher chance of assessment of basic mobility at discharge, osteoporosis prophylaxis, and future fall prophylaxis in former SSRI users compared with non-users. Overall, there was no association between current and former SSRI use and quality of inhospital care (Table S4).

\section{Sensitivity analysis}

The HRs of mortality did not materially change after multiple imputation of missing BMI values and adjustment for BMI (Tables S5 and S6). Changing the exposure definition, we identified 14,530 (21\%) current SSRI users, 1,116 (2\%) former users, and 52,841 (77\%) non-users. Patient characteristics in the new exposure groups were similar to the patient characteristics of the exposure groups used in the main analysis and the HRs of mortality were similar to the main analysis results (Tables $\mathrm{S} 7$ and $\mathrm{S} 8$ ).

\section{Discussion}

In this nationwide cohort study of hip fracture surgery patients, 30-day mortality and overall readmission were elevated for both current and former SSRI users. Those currently using SSRIs had an increased reoperation risk compared with non-users. However, SSRI use was not associated with increased risk of cardiovascular and bleeding complications and inferior quality of in-hospital care.

\section{Strengths and limitations}

The strengths of this study are the use of well-established, well-validated, and prospectively collected data from Danish population-based registries with complete follow-up. ${ }^{1924-26}$ The registries originate from a tax-supported and uniformly organized health care system, reducing the risk of selection bias. The validity of the hip fracture diagnosis is high, ${ }^{27,28}$ and the complete follow-up reduces the risk of differential misclassification. In general, our study included all elderly hip fracture patients aged 65 years or older in Denmark between 2006 and 2016. These patients are similar regarding age and gender to those included in other studies on hip 
Table I Baseline characteristics of hip fracture patients $(n=68,487)$ according to preoperative selective serotonin reuptake inhibitor use 2006-2016

\begin{tabular}{|c|c|c|c|c|c|c|c|c|}
\hline \multirow[t]{3}{*}{ Characteristics } & \multirow{2}{*}{\multicolumn{2}{|c|}{$\begin{array}{l}\text { All patients } \\
(N=68,487)\end{array}$}} & \multicolumn{6}{|c|}{ SSRI status } \\
\hline & & & \multicolumn{2}{|c|}{$\begin{array}{l}\text { Current users } \\
(\mathrm{N}=13,272)\end{array}$} & \multicolumn{2}{|c|}{$\begin{array}{l}\text { Former users } \\
(\mathrm{N}=\mathbf{2 , 7 7 7 )}\end{array}$} & \multicolumn{2}{|c|}{$\begin{array}{l}\text { Non-users } \\
(\mathrm{N}=52,438)\end{array}$} \\
\hline & $\mathbf{n}$ & $\%$ & $\bar{n}$ & $\%$ & $\bar{n}$ & $\%$ & $\bar{n}$ & $\%$ \\
\hline \multicolumn{9}{|l|}{ Age (years) } \\
\hline $65-74$ & $|3,27|$ & 19.4 & $|0,57|$ & 20.2 & 533 & 19.2 & 2,167 & 16.3 \\
\hline $75-84$ & 26,086 & 38.1 & 19,768 & 37.7 & 1,159 & 41.7 & 5,159 & 38.9 \\
\hline$\geq 85$ & 29,130 & 42.5 & 22,099 & 42.1 & $\mathrm{I}, 085$ & 39.1 & 5,946 & 44.8 \\
\hline \multicolumn{9}{|l|}{ Gender } \\
\hline Male & 19,750 & 28.8 & $|5,54|$ & 29.6 & 730 & 26.3 & 3,479 & 26.2 \\
\hline Female & 48,737 & 71.2 & 36,897 & 70.4 & 2,047 & 73.7 & 9,793 & 73.8 \\
\hline \multicolumn{9}{|l|}{ Marital status } \\
\hline Married & 20,300 & 29.6 & 16,105 & 30.7 & 842 & 30.3 & 3.353 & 25.3 \\
\hline Unmarried & 48,187 & 70.4 & 36,333 & 69.3 & 1,935 & 69.7 & 9,919 & 74.7 \\
\hline \multicolumn{9}{|l|}{ Housing } \\
\hline Own accommodation & 31,075 & 45.4 & 25,537 & 48.7 & 1,126 & 40.5 & 4,412 & 33.2 \\
\hline Homeless & 22 & $<0.1$ & 20 & 0.1 & 0 & 0.0 & 2 & $<0.1$ \\
\hline Residential institution & 7,105 & 10.4 & 4,213 & 8.0 & 408 & 14.7 & 2,484 & 18.7 \\
\hline Unknown & 30,285 & 44.2 & 22,668 & 43.2 & $\mathrm{I}, 243$ & 44.8 & 6,374 & 48.0 \\
\hline \multicolumn{9}{|l|}{ Fracture type } \\
\hline Fracture of femoral neck & 36,341 & 53.1 & 27,854 & 53.1 & $|, 45|$ & 52.3 & 7,036 & 53.0 \\
\hline Per- and subtrochanteric fracture & 32,146 & 46.9 & 24,584 & 46.9 & 1,326 & 47.7 & 6,236 & 46.9 \\
\hline \multicolumn{9}{|l|}{ Operation type } \\
\hline Alloplastic surgery & 46,859 & 68.4 & 35,843 & 68.4 & 1,902 & 68.5 & 9,114 & 68.7 \\
\hline Osteosynthesis & 21,628 & 31.6 & 16,595 & 31.6 & 875 & 31.5 & 4,158 & 31.3 \\
\hline \multicolumn{9}{|l|}{ Operation delay (hours) } \\
\hline$<24$ & $4 I, 67 \mid$ & 60.8 & 31,859 & 60.8 & $|, 72|$ & 62.0 & 8,091 & 61.0 \\
\hline $24-48$ & 12,517 & 18.3 & 9,646 & 18.4 & 461 & 16.6 & 2,410 & 18.1 \\
\hline$>48$ & 14,299 & 20.9 & 10,933 & 20.8 & 595 & 21.4 & $2,77 \mid$ & 20.9 \\
\hline \multicolumn{9}{|l|}{ Operation year } \\
\hline $2006-2010$ & $32,|3|$ & 46.9 & 23,822 & 45.4 & I,342 & 48.3 & 6,967 & 52.5 \\
\hline $2011-2016$ & 36,356 & 53.1 & 28,616 & 54.6 & 1,435 & 51.7 & 6,305 & 47.5 \\
\hline \multicolumn{9}{|l|}{ BMI $\left(\mathrm{kg} / \mathrm{m}^{2}\right)$} \\
\hline <18.5: underweight & 5,988 & 8.8 & 4,558 & 8.7 & 292 & 10.5 & 1,138 & 8.6 \\
\hline$\geq 18.5<25$ : normal weight & 31,582 & 46.1 & 24,390 & 46.5 & 1,254 & 45.2 & 5,938 & 44.7 \\
\hline$\geq 25$ : overweight or obese & 17,622 & 25.7 & 13,602 & 25.9 & 689 & 24.8 & 3,331 & 25.1 \\
\hline Unknown & 13,295 & 19.4 & 9,888 & 18.9 & 542 & 19.5 & 2,865 & 21.6 \\
\hline \multicolumn{9}{|l|}{ Charlson Comorbidity Index } \\
\hline Low $(0)$ & 27,283 & 39.8 & 22,505 & 42.9 & 840 & 30.3 & 3,938 & 29.7 \\
\hline Medium (I-2) & 27,787 & 40.6 & 20,365 & 38.8 & $\mathrm{I}, 244$ & 44.8 & 6,178 & 46.5 \\
\hline High (3+) & $13,4 \mid 7$ & 19.6 & 9,568 & 18.3 & 693 & 24.9 & 3,156 & 23.8 \\
\hline \multicolumn{9}{|l|}{ Comorbidity } \\
\hline Myocardial infarction & 3,762 & 5.5 & 2,820 & 5.4 & 151 & 5.4 & 791 & 6.0 \\
\hline Congestive heart failure & 6,289 & 9.2 & 4,632 & 8.8 & 291 & 10.5 & 1,366 & 10.3 \\
\hline Peripheral vascular disease & 5,511 & 8.1 & 4,060 & 7.7 & 267 & 9.6 & 1,184 & 8.9 \\
\hline Cerebrovascular disease & 12,678 & 18.5 & 8,467 & 16.2 & 689 & 24.8 & 3,522 & 26.5 \\
\hline Dementia & 6,733 & 9.8 & 3,859 & 7.4 & 433 & 15.6 & $2,44 I$ & 19.4 \\
\hline Chronic pulmonary disease & 8,663 & 12.7 & 6,191 & 11.8 & 496 & 17.9 & I,976 & 14.9 \\
\hline Connective tissue disease & 3,243 & 4.7 & 2,480 & 4.7 & 139 & 5.0 & 624 & 4.7 \\
\hline Ulcer disease & 3,855 & 5.6 & 2,673 & 5.1 & 224 & 8.1 & 958 & 7.2 \\
\hline Liver disease & 870 & 1.3 & 646 & 1.2 & 46 & 1.7 & 178 & 1.3 \\
\hline Diabetes type $I$ and 2 & 6,689 & 9.8 & 5,005 & 9.5 & 281 & 10.1 & $\mathrm{I}, 403$ & 10.6 \\
\hline Hemiplegia & 175 & 0.3 & 111 & 0.2 & 12 & 0.4 & 52 & 0.4 \\
\hline Moderate to severe renal disease & 2,688 & 3.9 & 1,973 & 3.4 & 132 & 4.8 & 583 & 4.4 \\
\hline Cancer & 10,957 & 16.0 & 8,351 & 15.9 & 501 & 18.0 & 2,105 & 15.9 \\
\hline
\end{tabular}


Table I (Continued)

\begin{tabular}{|c|c|c|c|c|c|c|c|c|}
\hline \multirow[t]{3}{*}{ Characteristics } & \multirow{2}{*}{\multicolumn{2}{|c|}{$\begin{array}{l}\text { All patients } \\
(\mathrm{N}=68,487)\end{array}$}} & \multicolumn{6}{|c|}{ SSRI status } \\
\hline & & & \multicolumn{2}{|c|}{$\begin{array}{l}\text { Current users } \\
(\mathrm{N}=\mid 3,272)\end{array}$} & \multicolumn{2}{|c|}{$\begin{array}{l}\text { Former users } \\
(\mathrm{N}=2,777)\end{array}$} & \multicolumn{2}{|c|}{$\begin{array}{l}\text { Non-users } \\
(\mathrm{N}=\mathbf{5 2 , 4 3 8 )}\end{array}$} \\
\hline & n & $\%$ & $\mathbf{n}$ & $\%$ & n & $\%$ & n & $\%$ \\
\hline NSAIDs & 7,681 & 11.2 & 5,869 & 11.2 & 334 & 12.0 & $\mathrm{I}, 478$ & 11.1 \\
\hline Corticosteroids & 4,158 & 6.1 & 3,068 & 5.9 & 186 & 6.7 & 904 & 6.8 \\
\hline Anticoagulants & 26,716 & 39.0 & 19,323 & 36.9 & $\mathrm{I}, 064$ & 38.3 & 6,329 & 47.7 \\
\hline Statins & 13,052 & 19.1 & 9,581 & 18.3 & 505 & 19.2 & 2,966 & 22.4 \\
\hline Non-SSRI antidepressants & 7,975 & 11.6 & 4,977 & 9.5 & 596 & 21.5 & 2,402 & 18.1 \\
\hline Antipsychotics & 4,992 & 7.3 & 2,899 & 5.5 & 319 & 11.5 & $\mathrm{I}, 774$ & 13.4 \\
\hline
\end{tabular}

Abbreviations: SSRI, selective serotonin reuptake inhibitor; NSAIDs, non-steroidal anti-inflammatory drugs.

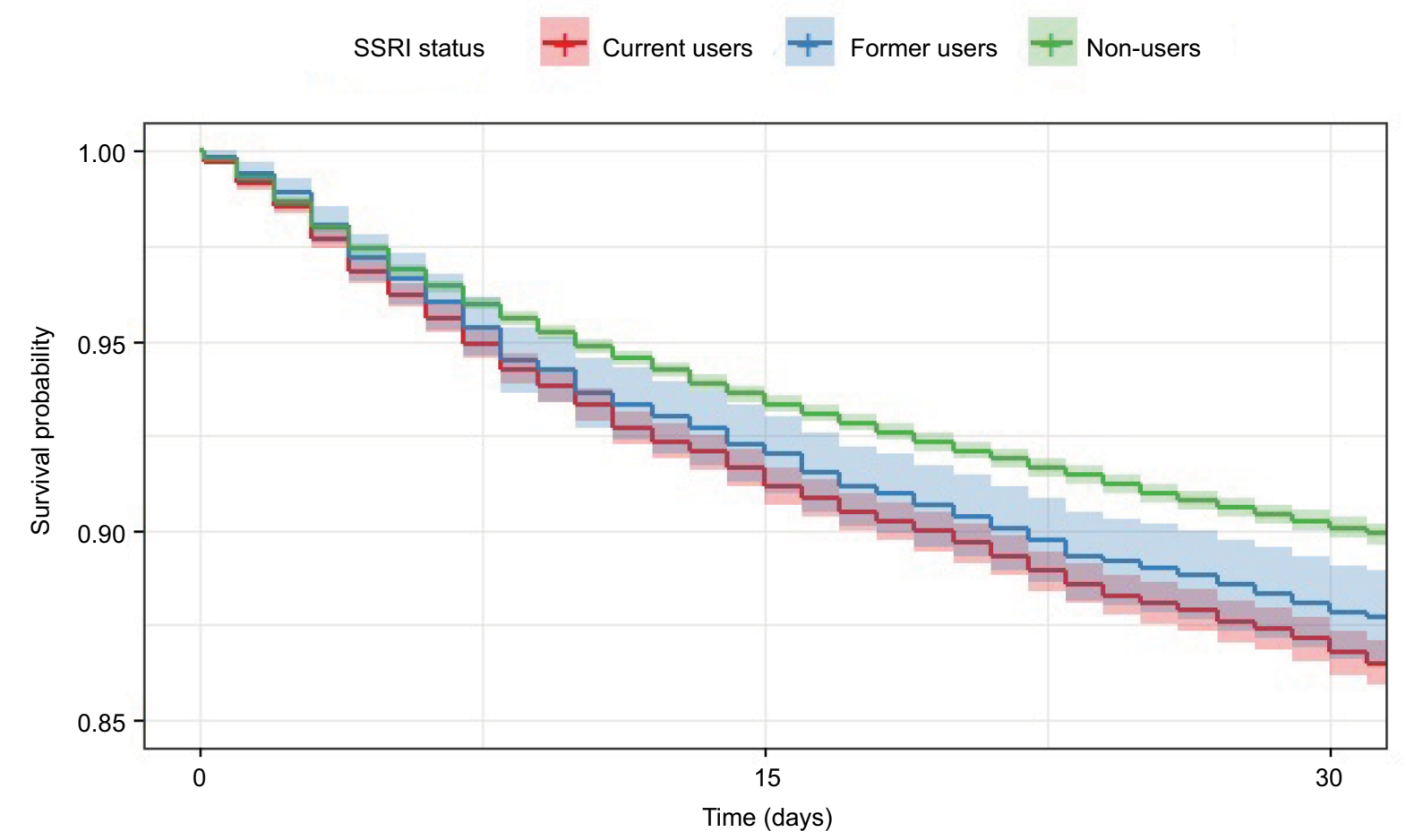

Number at risk

\begin{tabular}{|l|c|c|}
\hline 13,272 & 12,163 & 11,564 \\
\hline 2,777 & 2,563 & 2,446 \\
\hline 52,438 & 49,084 & 47,334 \\
\hline
\end{tabular}

Figure I Kaplan-Meyer survival curve showing mortality in hip fracture patients according to selective serotonin reuptake inhibitor (SSRI) use $2006-20$ I6.

fractures in the elderly. ${ }^{4,7}$ To date, this is the largest study examining the association between SSRI use and mortality, postoperative complications, and quality of in-hospital care in hip fracture patients.

We gathered comprehensive data on potential confounders including complete in-hospital comorbidity history com- piled in the $\mathrm{CCI}^{26}$ and history of specific diseases. However, we did not have information on the severity of diseases included in the CCI, on diseases treated in primary care, which were not severe enough to warrant a hospital diagnosis, or information on the underlying disease indication for SSRI prescription. However, we included information on 
Table 2 Cumulative incidences and HRs with $95 \% \mathrm{Cls}$ of mortality, readmission, reoperation, and postoperative complications within 30 days of hip fracture surgery according to selective serotonin reuptake inhibitor (SSRI) use 2006-2016 (N=68,487)

\begin{tabular}{|c|c|c|c|c|}
\hline & Event/total & $\begin{array}{l}\text { Incidence \% } \\
(95 \% \mathrm{Cl})\end{array}$ & $\begin{array}{l}\text { Unadjusted HR } \\
(95 \% \mathrm{Cl})\end{array}$ & $\begin{array}{l}\text { Adjusted }^{a} \text { HR } \\
\text { (95\% Cl) }\end{array}$ \\
\hline \multicolumn{5}{|l|}{ Mortality } \\
\hline Current users & I,755/I3,272 & $13.2(\mid 2.7-12.8)$ & $1.35(1.28-1.43)$ & $1.16(1.10-1.21)$ \\
\hline Former users & $338 / 2,777$ & $12.2(11.0-12.5)$ & $1.24(1.11-1.38)$ & $1.15(1.04-1.27)$ \\
\hline Non-users & $5,202 / 52,438$ & $9.9(9.7-10.2)$ & 1.00 & 1.00 \\
\hline \multicolumn{5}{|l|}{ Readmission ${ }^{\mathrm{b}}$} \\
\hline Current users & $1,192 / 6,305$ & $19.0(18.0-19.9)$ & $1.21(1.14-1.29)$ & I.II (1.02-1.20) \\
\hline Former users & $280 / 1,435$ & $19.6(17.5-21.6)$ & $1.24(1.10-1.40)$ & $1.13(1.01-1.27)$ \\
\hline Non-users & $4,642 / 28,616$ & $16.3(15.8-16.7)$ & 1.00 & 1.00 \\
\hline \multicolumn{5}{|l|}{ Reoperation } \\
\hline Current users & $749 / 13,272$ & $5.6(5.3-6.0)$ & $1.29(1.18-1.40)$ & $1.21(1 . \mid 1-1.31)$ \\
\hline Former users & $135 / 2,777$ & $4.9(4.1-5.7)$ & $1.10(0.92-1.30)$ & $1.04(0.84-1.28)$ \\
\hline Non-users & $2,353 / 52,438$ & $4.5(4.3-4.7)$ & 1.00 & 1.00 \\
\hline \multicolumn{5}{|l|}{ VTE } \\
\hline Current users & $96 / 13,272$ & $0.7(0.6-0.9)$ & $0.85(0.68-1.06)$ & $0.89(0.67-1.17)$ \\
\hline Former users & $22 / 2,777$ & $0.8(0.5-1.7)$ & $0.92(0.60-1.42)$ & $0.93(0.64-1.35)$ \\
\hline Non-users & $455 / 52,438$ & $0.9(0.8-0.9)$ & 1.00 & 1.00 \\
\hline \multicolumn{5}{|l|}{ MI } \\
\hline Current users & $109 / 13,272$ & $0.8(0.7-1.0)$ & I.04 (0.84-I.28) & $\mathrm{I} .03(0.8 \mathrm{I}-\mathrm{I} .30)$ \\
\hline Former users & I8/2,777 & $0.6(0.4-1.0)$ & $0.82(0.5|-| .3 \mid)$ & $0.89(0.57-1.40)$ \\
\hline Non-users & $419 / 52,438$ & $0.8(0.7-0.9)$ & 1.00 & 1.00 \\
\hline \multicolumn{5}{|l|}{ Stroke } \\
\hline Current users & $176 / 13,272$ & $1.3(1.1-1.5)$ & $1.06(0.90-1.25)$ & $0.93(0.80-1.09)$ \\
\hline Former users & $25 / 2,777$ & $0.9(0.6-1.3)$ & $0.72(0.48-1.07)$ & $0.67(0.44-1.01)$ \\
\hline Non-users & $662 / 52,438$ & $1.3(1.2-1.4)$ & 1.00 & 1.00 \\
\hline \multicolumn{5}{|l|}{ Bleeding } \\
\hline Current users & $218 / 13,272$ & $1.6(1.4-1.9)$ & $1.17(1.01-1.36)$ & $1.06(0.89-1.28)$ \\
\hline Former users & $43 / 2,777$ & $1.5(I . I-2.1)$ & $1.09(0.8 \mathrm{I}-\mathrm{I} .49)$ & $1.06(0.69-1.64)$ \\
\hline Non-users & $750 / 52,438$ & $1.4(1.3-1.5)$ & 1.00 & 1.00 \\
\hline
\end{tabular}

Notes: aAjusted for age, gender, marital status, operation year, Ml, congestive heart failure, peripheral vascular disease, dementia, chronic pulmonary disease, connective tissue disease, ulcer disease, liver disease, diabetes type I and 2, hemiplegia, moderate to severe renal disease, cancer, non-steroidal anti-inflammatory drugs, corticosteroids, anticoagulants, statins, non-SSRI antidepressants, antipsychotics, and clustering by unit setting. ${ }^{\circ}$ Restricted to hip fracture patients operated on between $20 \mathrm{II}$ and $20 \mathrm{I} 6$.

Abbreviations: VTE, venous thromboembolism; MI, myocardial infarction.

other medication, which may indicate treatment of conditions not captured in the CCI. The registries we used did not contain information on socioeconomic status, smoking, alcohol use, and other lifestyle factors. Furthermore, almost half of the patients were missing data on housing, making control of confounding difficult. Thus, we were not able to control for the potential confounding of social deprivation and lack of these data may have resulted in unmeasured and residual confounding. Information on comorbidities, other medication, marital status, and unit setting may contribute to control of confounding, but is not an adequate measure of social deprivation.

We included former SSRI users as a negative control. That is, we anticipated that former users were more similar to current users than non-users regarding potential confounding factors such as socioeconomic status and lifestyle factors.
Thus, if the effect of SSRI exposure on mortality was caused by the medication itself, we would anticipate only seeing an effect in current users and not in former users. However, this was not the case, and the observed association between SSRI use and mortality may rather be caused by underlying risk factors. ${ }^{29}$

We did not have information about compliance. In our study, non-compliance would cause a misclassification of non-users as users, and therefore the observed association between SSRI use and mortality, readmission, or reoperation risk might actually be higher. However, as the patients redeemed the prescriptions, our estimates most likely reflect actual drug use. Even considering misclassification, dispensed prescriptions are considered a good measure of medication intake. ${ }^{30}$ Furthermore, we had no data on in-hospital medication use. This may not have influenced the outcome 


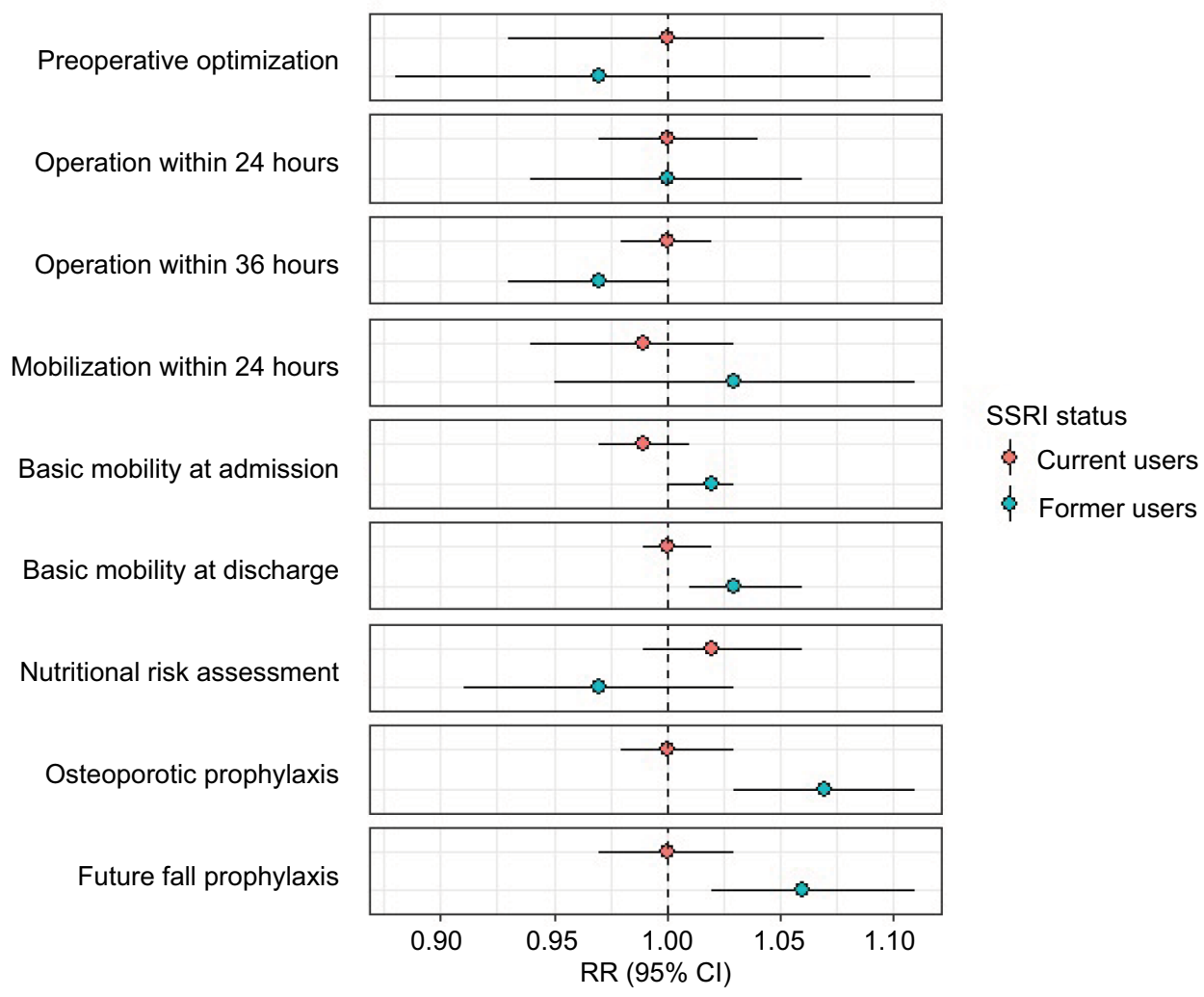

Figure 2 Adjusted RRs with $95 \%$ Cls of quality of in-hospital care comparing current and former selective serotonin reuptake inhibitor (SSRI) users with non-users (reference) 2015-2016 (N=11,363).

Notes: Adjusted for age, gender, marital status, operation year, myocardial infarction, congestive heart failure, peripheral vascular disease, dementia, chronic pulmonary disease, connective tissue disease, ulcer disease, liver disease, diabetes type I and 2, hemiplegia, moderate to severe renal disease, cancer, non-steroidal anti-inflammatory drugs, corticosteroids, anticoagulants, statins, non-SSRI antidepressants, antipsychotics, and clustering by unit setting.

since hip fracture surgery is an acute procedure with short length of hospital stay.

\section{Comparison with other studies}

We observed an equally increased mortality risk in current and former SSRI users. This suggests that rather than being a risk factor in itself, SSRI use may be a marker of underlying risk factors such as psychiatric illness, socioeconomic status, and lifestyle factors (smoking, alcohol misuse, and physical inactivity). These results are consistent with those obtained by Auerbach et al, showing an increased mortality in SSRI users compared with non-users after major surgery, including approximately $2 \%$ hip fracture surgeries. ${ }^{12}$ However, the association found by Auerbach et al was attenuated in patients with depression suggesting that the underlying psychiatric indication for SSRI use may explain the increased risk rather than SSRIs in itself. ${ }^{12} \mathrm{~A}$ meta-analysis by Maslej et al found an increased mortality in antidepressant users compared to non-users in the general population independent of treatment indication. ${ }^{31}$ The most common indications for SSRI treat- ment are depression and anxiety ${ }^{10}$ and a systematic review by Eaton et al showed that depression and anxiety correlate with increased mortality. ${ }^{32}$ Mortality in hip fracture patients may also be influenced by socioeconomic status, ${ }^{33}$ and Marinacci et al found an association between lower education level and mortality. ${ }^{34}$ Lower education level is further associated with increased risk of psychiatric admission due to schizophrenia, alcoholism, drug dependency, affective psychosis, neurosis, and personality disorder.$^{35}$ Finally, Seitz et al found no difference in 30-day mortality between current (9.1\%) and former (9.4\%) serotonergic antidepressant users undergoing hip fracture surgery. ${ }^{36}$ However, they did not include a non-user group, which distorts the association between SSRI use and mortality.

Our findings of an increased overall readmission risk in current and former SSRI users compared with non-users is consistent with the findings reported by Auerbach et al in major surgery patients. In their study, this association persisted in patients receiving SSRIs for depression, but not in patients receiving SSRIs for other reasons. ${ }^{12}$ This 
also suggests that SSRI use may not be a risk factor in itself but a marker of underlying disease or risk factors. A metaanalysis by Pizzi et al found no association between SSRI use and readmission in patients with coronary heart disease and depression, further supporting our results that SSRI use may not be a risk factor in itself. ${ }^{37}$

Another important finding was that current SSRI users had an increased reoperation risk compared with non-users, whereas the risk was not elevated in former users. A possible explanation for this could be that SSRI use may increase the likelihood of complications necessitating reoperation. There are different reasons for performing reoperation, eg, wound dehiscence, infection, and bleeding, ${ }^{20}$ and these complications may be more frequent in SSRI users. Gärtner et al found an association between SSRI use and reoperation due to bleeding after breast cancer surgery. ${ }^{38}$ However, Tully et al showed no association between serotonergic antidepressant use and reoperation due to infection or bleeding after coronary artery bypass graft surgery. ${ }^{39}$ Further research is needed to establish the association between SSRI use and reoperation risk due to different causes in hip fracture patients.

We found little evidence of an association between SSRI and the risk of VTE, MI, stroke, and bleeding. To our knowledge, no other studies have investigated the association between SSRI use and the previously mentioned postoperative complications following hip fracture surgery. Auerbach et al found an association between SSRI use and postoperative bleeding in major surgery patients. However, they had a broader bleeding definition, including bleeding following procedure, and they included both acute and elective operations. ${ }^{12}$ Tully et al showed no association between SSRI use and MI, stroke, or bleeding after coronary artery bypass graft surgery, ${ }^{39}$ supporting our findings.

The present study did not find any difference between SSRI non-users and users regarding quality of in-hospital care. This is important and in line with efforts of European governments to reduce social inequality in treatment of patients. ${ }^{40}$ However, we have no information on quality of patient care outside hospital settings. Previous research suggests lower 30-day mortality in hip fracture patients who received higher quality of care. ${ }^{5}$ Quality of in-hospital care may not explain the increased mortality associated with SSRI use in our study.

\section{Implications of findings}

One issue emerging from our findings is the question about discontinuation of SSRI treatment after hip fracture surgery. Since hip fracture is an acute condition, it is not possible to stop treatment before surgery. Our analysis suggests that stopping
SSRI treatment after surgery would not change the mortality and overall readmission since these were similar in current and former users compared with non-users. We found that overall reoperation was augmented in current users, but not in former users compared with non-users. However, pausing SSRI treatment without a complete discussion of the risks and benefits is unwarranted. Our findings call for increased clinical awareness of hip fracture patients using SSRIs as they may have an increased risk of mortality, unplanned readmission, and reoperation. This patient group may be more prone to adverse outcomes after surgery regardless of the indication for SSRI treatment and may benefit from improved models of care. The follow-up care in Denmark is carried out by the municipality. Our findings suggest that hip fracture patients currently or formerly using SSRIs may benefit from closer follow-up and better communication between hospital, municipality, and general practitioner. However, the content and implementation of such improvements are beyond the scope of this paper. In future studies, it may be relevant to investigate how social deprivation influences surgical outcomes for these patients.

\section{Conclusion}

Thirty-day mortality and overall readmission in hip fracture patients were elevated in both current and former SSRI users compared with non-users. Those currently using SSRIs had an increased overall reoperation risk compared with nonusers. However, SSRI use was not associated with increased risk of cardiovascular and bleeding complications and lower quality of in-hospital care.

\section{Data availability}

The authors are not authorized to share the data as it were assessed via the data custodian, ie, the Danish National Data Board.

\section{Acknowledgments}

We thank the staff of the hospital departments caring for patients with hip fracture for their continuous effort and contribution to acquisition of the data in the Danish Multidisciplinary Hip Fracture Registry. The Independent Research Fund Denmark (grant number 6120-00034) funded this work. The funder had no role in the study design; in the collection, analysis, and interpretation of data; in the writing of the report; and in the decision to submit the article for publication. The researchers are independent from the funder. The study results were presented at the Danish Orthopedic Society Congress in October 2017 and at the PhD Day at Aarhus University in January 2018. 


\section{Author contributions}

All authors made substantial contributions to conception and design, acquisition of data, or analysis and interpretation of data; took part in drafting the article or revising it critically for important intellectual content; gave final approval of the version to be published; and agree to be accountable for all aspects of the work.

\section{Disclosure}

The authors report no conflicts of interest in this work.

\section{References}

1. Requena G, Abbing-Karahagopian V, Huerta C, et al. Incidence rates and trends of hip/femur fractures in five European countries: comparison using e-healthcare records databases. Calcif Tissue Int. 2014;94(6):580-589.

2. Polinder S, Meerding WJ, van Baar ME, et al. Cost estimation of injury-related hospital admissions in 10 European countries. JTrauma. 2005;59(6): 1283-1290.

3. de Luise C, Brimacombe M, Pedersen L, Sørensen HT. Comorbidity and mortality following hip fracture: a population-based cohort study. Aging Clin Exp Res. 2008;20(5):412-418.

4. Roche JJ, Wenn RT, Sahota O, Moran CG. Effect of comorbidities and postoperative complications on mortality after hip fracture in elderly people: prospective observational cohort study. $B M J$. 2005;331(7529):1374.

5. Nielsen KA, Jensen NC, Jensen CM, et al. Quality of care and 30 day mortality among patients with hip fractures: a nationwide cohort study. BMC Health Serv Res. 2009;9:186.

6. Coupland C, Dhiman P, Morriss R, Arthur A, Barton G, Hippisley-Cox J. Antidepressant use and risk of adverse outcomes in older people: population based cohort study. BMJ. 2011;343:d4551.

7. Lawrence VA, Hilsenbeck SG, Noveck H, Poses RM, Carson JL. Medical complications and outcomes after hip fracture repair. Arch Intern Med. 2002;162(18):2053-2057.

8. Vieira ER, Palmer RC, Chaves PH. Prevention of falls in older people living in the community. BMJ. 2016;353:i1419.

9. Medstat.dk [homepage on the Internet]. The Danish Health Data Authority. Available from: http://medstat.dk/. Accessed July 5, 2018.

10. Noordam R, Aarts N, Verhamme KM, Sturkenboom MC, Stricker BH, Visser LE. Prescription and indication trends of antidepressant drugs in the Netherlands between 1996 and 2012: a dynamic population-based study. Eur J Clin Pharmacol. 2015;71(3):369-375.

11. Wu CS, Chang CM, Chen CY, et al. Association between antidepressants and venous thromboembolism in Taiwan. J Clin Psychopharmacol. 2013;33(1):31-37.

12. Auerbach AD, Vittinghoff E, Maselli J, Pekow PS, Young JQ, Lindenauer PK. Perioperative use of selective serotonin reuptake inhibitors and risks for adverse outcomes of surgery. JAMA Intern Med. 2013;173(12):1075-1081.

13. Movig KL, Janssen MW, de Waal Malefijt J, Kabel PJ, Leufkens HG, Egberts AC. Relationship of serotonergic antidepressants and need for blood transfusion in orthopedic surgical patients. Arch Intern Med. 2003;163(19):2354-2358.

14. van Haelst IM, Egberts TC, Doodeman HJ, et al. Use of serotonergic antidepressants and bleeding risk in orthopedic patients. Anesthesiology. 2010;112(3):631-636.

15. Statistics Denmark. Statistical Yearbook. 121th ed. Copenhagen: Statistics Denmark; 2017.
16. Sørensen HT, Christensen T, Schlosser HK, Pedersen L. Use of Medical Databases in Clinical Epidemiology. 2nd ed. Aarhus: SUN-TRYK, Aarhus Universitet; 2009.

17. Schmidt M, Pedersen L, Sørensen HT. The Danish Civil Registration System as a tool in epidemiology. Eur J Epidemiol. 2014;29(8):541-549.

18. Schmidt M, Schmidt SA, Sandegaard JL, Ehrenstein V, Pedersen L, Sørensen HT. The Danish National Patient Registry: a review of content, data quality, and research potential. Clin Epidemiol. 2015;7:449-490.

19. Johannesdottir SA, Horváth-Puhó E, Ehrenstein V, Schmidt M, Pedersen L, Sørensen HT. Existing data sources for clinical epidemiology: The Danish National Database of Reimbursed Prescriptions. Clin Epidemiol. 2012;4:303-313.

20. Centre for Clinical Epidemiology and Biostatistics North. The Danish Multidisciplinary Hip Fracture Register - National Annual Report 2017 : The Danish Clinical Registries; 2017. Available from: https://www.sundhed.dk/content/cms/62/4662_hofte-fraktur-\%C3\%A5rsrapport_2017. pdf. Accessed August 7, 2018. Danish.

21. Charlson ME, Pompei P, Ales KL, Mackenzie CR. A new method of classifying prognostic comorbidity in longitudinal studies: development and validation. J Chronic Dis. 1987;40(5):373-383.

22. Shrier I, Platt RW. Reducing bias through directed acyclic graphs. $B M C$ Med Res Methodol. 2008;8(1):70.

23. Pedersen AB, Mikkelsen EM, Cronin-Fenton D, et al. Missing data and multiple imputation in clinical epidemiological research. Clin Epidemiol. 2017;9:157-166.

24. Sundbøll J, Adelborg K, Munch T, et al. Positive predictive value of cardiovascular diagnoses in the Danish National Patient Registry: a validation study. BMJ Open. 2016;6(11):e012832.

25. Wildenschild C, Mehnert F, Thomsen RW, et al. Registration of acute stroke: validity in the Danish Stroke Registry and the Danish National Registry of Patients. Clin Epidemiol. 2014;6:27-36.

26. Thygesen SK, Christiansen CF, Christensen S, Lash TL, Sørensen HT. The predictive value of ICD-10 diagnostic coding used to assess Charlson comorbidity index conditions in the population-based Danish National Registry of Patients. BMC Med Res Methodol. 2011;11:83.

27. Baron JA, Lu-Yao G, Barrett J, Mclerran D, Fisher ES. Internal validation of Medicare claims data. Epidemiology. 1994;5(5):541-544.

28. Hudson M, Avina-Zubieta A, Lacaille D, Bernatsky S, Lix L, Jean S. The validity of administrative data to identify hip fractures is high--a systematic review. J Clin Epidemiol. 2013;66(3):278-285.

29. Lawlor DA, Tilling K, Davey Smith G. Triangulation in aetiological epidemiology. Int J Epidemiol. 2016;45(6):1866-1886.

30. Schneeweiss S, Avorn J. A review of uses of health care utilization databases for epidemiologic research on therapeutics. J Clin Epidemiol. 2005;58(4):323-337.

31. Maslej MM, Bolker BM, Russell MJ, et al. The mortality and myocardial effects of antidepressants are moderated by preexisting cardiovascular disease: a meta-analysis. Psychother Psychosom. 2017;86(5): 268-282.

32. Eaton WW, Martins SS, Nestadt G, Bienvenu OJ, Clarke D, Alexandre P. The burden of mental disorders. Epidemiol Rev. 2008;30:1-14.

33. Thorne K, Johansen A, Akbari A, Williams JG, Roberts SE. The impact of social deprivation on mortality following hip fracture in England and Wales: a record linkage study. Osteoporos Int. 2016;27(9): $2727-2737$.

34. Marinacci C, Grippo F, Pappagallo M, et al. Social inequalities in total and cause-specific mortality of a sample of the Italian population, from 1999 to 2007. Eur J Public Health. 2013;23(4):582-587.

35. Tiikkaja S, Sandin S, Malki N, Modin B, Sparén P, Hultman CM. Social class, social mobility and risk of psychiatric disorder--a populationbased longitudinal study. PLoS One. 2013;8(11):e77975.

36. Seitz DP, Bell CM, Gill SS, et al. Risk of perioperative blood transfusions and postoperative complications associated with serotonergic antidepressants in older adults undergoing hip fracture surgery. J Clin Psychopharmacol. 2013;33(6):790-798. 
37. Pizzi C, Rutjes AW, Costa GM, Fontana F, Mezzetti A, Manzoli L. Meta-analysis of selective serotonin reuptake inhibitors in patients with depression and coronary heart disease. Am J Cardiol. 2011;107(7):972-979.

38. Gärtner R, Cronin-Fenton D, Hundborg HH, et al. Use of selective serotonin reuptake inhibitors and risk of re-operation due to post-surgical bleeding in breast cancer patients: a Danish population-based cohort study. BMC Surg. 2010;10:3.
39. Tully PJ, Cardinal T, Bennetts JS, Baker RA. Selective serotonin reuptake inhibitors, venlafaxine and duloxetine are associated with in hospital morbidity but not bleeding or late mortality after coronary artery bypass graft surgery. Heart Lung Circ. 2012;21(4):206-214.

40. World Health Organization Europe. Parma Declaration on Environment and Health. Fifth Ministerial Conference on Environment and Health. Parma, Italy; 2010. Available from: http://www.euro.who.int/_data/ assets/pdf_file/0011/78608/E93618.pdf. Accessed August 07, 2018. 


\section{Supplementary materials}

Table SI ICD-8 and ICD-I0 diagnosis codes from the Danish National Patient Registry

\begin{tabular}{|c|c|c|}
\hline Variable & Codes & \\
\hline Disease & ICD-8 diagnosis codes & ICD-I0 diagnosis codes \\
\hline Myocardial infarction & 410 & $121 ; 122 ; 123$ \\
\hline Congestive heart failure & $\begin{array}{l}\text { 427.09; 427.10; 427.II; 427.19; } \\
428.99 ; 782.49\end{array}$ & 150; III.0; II3.0; II3.2 \\
\hline Peripheral vascular disease & 440; 44I; 442; 443; 444; 445 & I70; 17I; I72; 173; I74; 177 \\
\hline Cerebrovascular disease & $430-438$ & I60-I69; G45; G46 \\
\hline Dementia & 290.09-290.19; 293.09 & F00-F03; F05.I; G30 \\
\hline $\begin{array}{l}\text { Chronic pulmonary } \\
\text { disease }\end{array}$ & $490-493 ; 515-518$ & 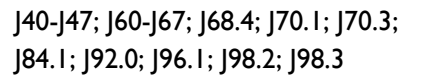 \\
\hline Connective tissue disease & $712 ; 716 ; 734 ; 446 ; 135.99$ & $\begin{array}{l}\text { M05; M06; M08; M09; M30; M3I; } \\
\text { M32; M33; M34; M35; M36; D86 }\end{array}$ \\
\hline Ulcer disease & $530.91 ; 530.98 ; 531-534$ & $\mathrm{~K} 22 . \mathrm{I} ; \mathrm{K} 25-\mathrm{K} 28$ \\
\hline Liver disease & $\begin{array}{l}57 I ; 573.01 ; 573.04 ; 070.00 ; 070.02 \\
070.04 ; 070.06 ; 070.08 ; 573.00 \\
456.00-456.09\end{array}$ & $\begin{array}{l}\mathrm{BI} 8 ; \mathrm{K} 70.0-\mathrm{K} 70.3 ; \mathrm{K} 70.9 ; \mathrm{K} 7 \mathrm{I} \text { K73; } \\
\mathrm{K} 74 ; \mathrm{K} 76.0 ; \mathrm{BI} 5.0 ; \mathrm{BI} 6.0 ; \mathrm{BI} 6.2 ; \\
\mathrm{BI9.0;} \mathrm{K70.4;} \mathrm{K72;} \mathrm{K76.6;} 185\end{array}$ \\
\hline Diabetes type I and type 2 & $\begin{array}{l}249.00 ; 249.06 ; 249.07 ; 249.09250 .00 \\
250.06 ; 250.07 ; 250.09 ; 249.0 I- \\
249.05 ; 249.08 ; 250.0 I-250.05 ; 250.08\end{array}$ & $\begin{array}{l}\text { EI0.0, EI0.I; EI0.9 EII.0; EII.I; } \\
\text { EII.9; EI0.2-EI0.8; EII.2-EII.8 }\end{array}$ \\
\hline Hemiplegia & 344 & G8I; G82 \\
\hline $\begin{array}{l}\text { Moderate to severe renal } \\
\text { disease }\end{array}$ & $\begin{array}{l}403 ; 404 ; 580-583 ; 584 ; 590.09 \\
593.19 ; 753.10-753.19 ; 792\end{array}$ & $\begin{array}{l}\text { II 2; II3; N00-N05; N07; NII; NI4; } \\
\text { NI7-NI 9; Q6I }\end{array}$ \\
\hline Cancer & $\begin{array}{l}\text { |40-194; 204-207; 200-203; 275.59; } \\
\text { |95-।98; } 199\end{array}$ & $\begin{array}{l}\mathrm{C} 00-\mathrm{C} 75 ; \mathrm{C} 9 \mathrm{I}-\mathrm{C} 95 ; \mathrm{C} 8 \mathrm{I}-\mathrm{C} 85 \\
\mathrm{C} 88 ; \mathrm{C} 90 ; \mathrm{C} 96 ; \mathrm{C} 76-\mathrm{C} 80\end{array}$ \\
\hline Intracranial bleeding & & $160-162$ \\
\hline \multicolumn{3}{|l|}{ bleeding } \\
\hline Hemothorax & & J942 \\
\hline Acute ulcer with bleeding & & $\mathrm{K} 250, \mathrm{~K} 260, \mathrm{~K} 270, \mathrm{~K} 280$ \\
\hline $\begin{array}{l}\text { Acute ulcer with bleeding } \\
\text { and perforation }\end{array}$ & & $\mathrm{K} 252, \mathrm{~K} 262, \mathrm{~K} 272, \mathrm{~K} 282$ \\
\hline \multicolumn{3}{|l|}{ ulcer with bleeding } \\
\hline $\begin{array}{l}\text { ulcer with bleeding and } \\
\text { perforation }\end{array}$ & & K256, K266, K276, K286 \\
\hline Acute bleeding gastritis & & K290 \\
\hline \multicolumn{3}{|l|}{ rectum } \\
\hline Gastrointestinal bleeding & & K920-K922 \\
\hline Hematuria & & R3I, N02 \\
\hline Airway bleeding & & R04 \\
\hline Deep venous & & $|80|-\mid 803$ \\
\hline \multicolumn{3}{|l|}{ thromboembolism } \\
\hline Lung embolism & & 126 \\
\hline Acute myocardial & & 121 \\
\hline \multicolumn{3}{|l|}{ infarction } \\
\hline Brain infarction & & 163 \\
\hline Apoplexy, unspecified & & 164 \\
\hline Transitory cerebral & & G459 \\
\hline infarction & & \\
\hline
\end{tabular}


Table S2 Codes from the Danish Multidisciplinary Hip Fracture Registry

\begin{tabular}{|c|c|}
\hline Description & Codes \\
\hline \multicolumn{2}{|l|}{ Housing } \\
\hline Procedure code specifying housing & ZZ8050 \\
\hline Own accommodation & ZRSBOI \\
\hline Own accommodation in association with an institution & ZRSBOIA \\
\hline Homeless & ZRSB02 \\
\hline Residential institution & ZRSB04 \\
\hline No information on housing & ZRSB09 \\
\hline \multicolumn{2}{|l|}{ Fracture type } \\
\hline Fracture of the femoral neck & S72.0 \\
\hline Pertrochanteric fracture & S72.I \\
\hline Subtrochanteric fracture & S72.2 \\
\hline \multicolumn{2}{|l|}{ Operation type } \\
\hline Primary insertion of joint prosthesis in hip joint & KNFB.0-99 \\
\hline Fracture treatments in femur (including osteosynthesis) & KNFJ.4-9 \\
\hline \multicolumn{2}{|l|}{ BMI } \\
\hline Procedure code determining BMI & ZZ0242 \\
\hline BMI I0-80 & VPH00IO - VPH0080 \\
\hline BMI I0-80 & VPKIOK00 - VPK80K00 \\
\hline \multicolumn{2}{|l|}{ Assessment of the patient's nutritional risk } \\
\hline Preparation of nutritional plan & ZZ2009C \\
\hline Assessment: no indication for preparation of nutritional plan & ZZ2009D \\
\hline \multicolumn{2}{|l|}{ Systematic pain assessment during mobilization of the patient } \\
\hline Systematic assessment of pain using pain scale & ZZV008A \\
\hline Pain assessment attempted: not possible & ZZV008Z \\
\hline \multicolumn{2}{|l|}{ Early mobilization within 24 hours of surgery } \\
\hline Early mobilization commenced & ZZP0030A \\
\hline Assessed, no indication for early mobilization & ZZP0030C \\
\hline Date of mobilization (eg, ZT20I60602) & $\mathrm{ZT}^{\mathrm{a}}$ \\
\hline Time of mobilization (eg, ZUI430) & $Z^{a}$ \\
\hline \multicolumn{2}{|l|}{ Assessment of basic mobility before admission for hip fracture } \\
\hline Assessment of the basic mobility prior to fracture & ZZV020GI \\
\hline Cumulated Ambulation Score (CAS) & ZRRA00 - ZRRA09 \\
\hline \multicolumn{2}{|l|}{ Assessment of basic mobility before discharge } \\
\hline Assessment of basic mobility at discharge & ZZV020G2 \\
\hline CAS & ZRRA00 - ZRRA09 \\
\hline \multicolumn{2}{|l|}{ Initiation of rehabilitation program } \\
\hline Preparation of rehabilitation plan, general rehabilitation & ZZ0I75X \\
\hline Preparation of rehabilitation plan, specialized rehabilitation & ZZ0I75Y \\
\hline Preparation of rehabilitation plan, rehabilitation in the specialized level & ZZ0I75V \\
\hline Assessment of need for rehabilitation, no rehabilitation & ZZOI72W \\
\hline \multicolumn{2}{|l|}{ Osteoporosis prophylaxis } \\
\hline Treatment with medicine for osteoporosis & BLHM7 \\
\hline Evaluation of the indication for drug therapy for osteoporosis & ZZVOIOAIA \\
\hline Pending complete investigation regarding indication for drug therapy for osteoporosis & ZZVOIOAIX \\
\hline \multicolumn{2}{|l|}{ Fall prophylaxis } \\
\hline Offer of fall prophylaxis given & ZZ5707BI \\
\hline Assessment of need for fall prophylaxis: no indication & ZZ5707A \\
\hline \multicolumn{2}{|l|}{ Surgery delay } \\
\hline Indicates the percentage of patients who are operated on within 24 hours of arrival at hospital & $2 \mathrm{~A}$ \\
\hline Indicates the percentage of patients who are operated on within 36 hours of arrival at hospital & $2 B$ \\
\hline
\end{tabular}

Note: a Number specifying the date or time of mobilization. 
Table S3 Anatomical Therapeutic Chemical (ATC) codes from the Danish National Database of Reimbursed Prescriptions

\begin{tabular}{ll}
\hline Selective serotonin reuptake inhibitor (SSRI) & ATC codes \\
\hline Citalopram & N06AB04 \\
Escitalopram & N06ABI0 \\
Fluoxetine & N06AB03 \\
Fluvoxamine & N06AB08 \\
Paroxetine & N06AB06 \\
Sertraline & N06AA, N06AF, N06AG, N06AX \\
Other medication & N05A \\
Non-SSRI antidepressants & B0IA \\
Antipsychotics & M0IA \\
Antithrombotic medicine & H02AB \\
Non-steroidal anti-inflammatory drugs & CI0AA \\
Corticosteroids & Statins \\
\hline
\end{tabular}

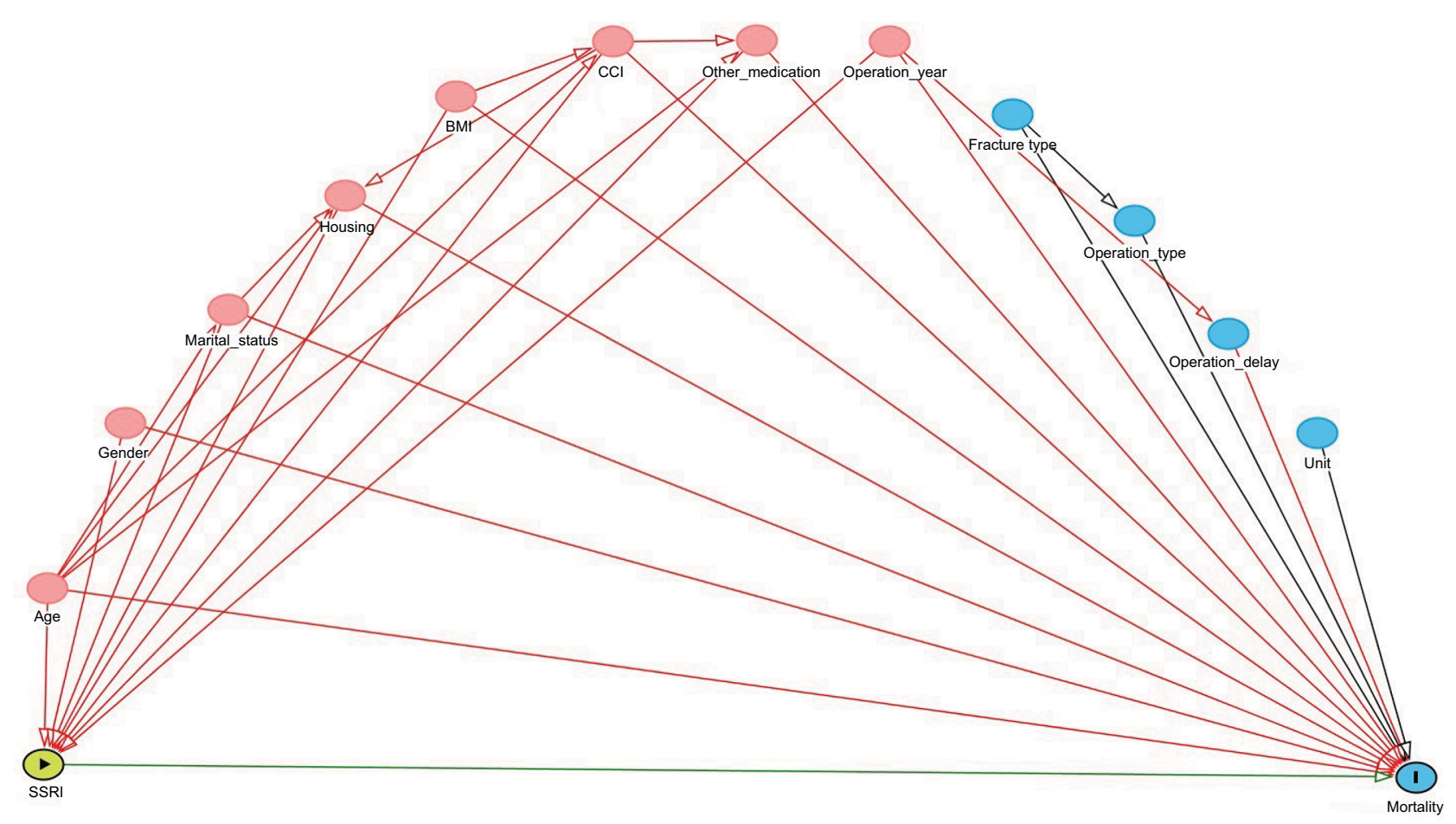

Figure SI Directed acyclic graph of the possible relationship between important covariates and mortality in hip fracture patients. Abbreviations: SSRI, selective serotonin reuptake inhibitor; $\mathrm{CCl}$, Charlson Comorbidity Index. 
Table S4 Unadjusted and adjusted RRs with $95 \%$ Cls of quality of in-hospital care according to selective serotonin reuptake inhibitor (SSRI) use 20I5-2016 ( $\mathrm{N}=1 \mathrm{I}, 363)$

\begin{tabular}{|c|c|c|c|}
\hline & Fulfilment (\%) & Unadjusted RR $(95 \% \mathrm{Cl})$ & Adjusted $^{a}$ RR $(95 \%$ Cl) \\
\hline Preoperative optimization & $4,301(37.9)$ & & \\
\hline Current user & $649(37.2)$ & $0.98(0.90-1.07)$ & $1.00(0.93-1.07)$ \\
\hline Former user & $161(37.0)$ & $0.97(0.83-1.14)$ & $0.97(0.88-1.09)$ \\
\hline Non-user & $3,491(38.0)$ & 1.00 & 1.00 \\
\hline Surgery within 24 hours & $7,75 I(68.2)$ & & \\
\hline Current user & $\mathrm{I}, \mathrm{I} 75(67.4)$ & $0.99(0.93-1.05)$ & $1.00(0.97-1.04)$ \\
\hline Former user & $291(66.9)$ & $0.98(0.87-1.10)$ & $1.00(0.94-1.06)$ \\
\hline Non-user & $6,285(68.4)$ & 1.00 & 1.00 \\
\hline Surgery within 36 hours & $9,64 \mid(84.8)$ & & \\
\hline Current user & I,47I (84.4) & $0.99(0.94-1.05)$ & $1.00(0.98-1.02)$ \\
\hline Former user & $354(81.4)$ & $0.96(0.86-1.06)$ & $0.97(0.93-1.00)$ \\
\hline Non-user & $7,816(85.1)$ & 1.00 & 1.00 \\
\hline Mobilization within 24 hours & $6,483(57.1)$ & & \\
\hline Current user & $952(54.6)$ & $0.95(0.89-1.02)$ & $0.99(0.94-1.03)$ \\
\hline Former user & $249(57.2)$ & $1.00(0.88-1.13)$ & $1.03(0.95-1.11)$ \\
\hline Non-user & $5,282(57.5)$ & 1.00 & 1.00 \\
\hline Basic mobility at admission & $10,383(91.4)$ & & \\
\hline Current user & $1,569(90.0)$ & $0.98(0.93-1.04)$ & $0.99(0.97-1.01)$ \\
\hline Former user & $402(92.4)$ & $1.01(0.91-1.12)$ & $1.02(1.00-1.03)$ \\
\hline Non-user & $8,412(91.6)$ & 1.00 & 1.00 \\
\hline Basic mobility at discharge & $9,945(87.5)$ & & \\
\hline Current user & $\mathrm{I}, 52 \mathrm{I}(97.3)$ & $1.00(0.94-1.05)$ & $1.00(0.99-1.02)$ \\
\hline Former user & $391(89.9)$ & $1.03(0.93-1.14)$ & $1.03(1.01-1.06)$ \\
\hline Non-user & $8,033(87.5)$ & 1.00 & 1.00 \\
\hline Nutritional status assessment & $9,304(81.9)$ & & \\
\hline Current user & $\mathrm{I}, 449(83.1)$ & $1.02(0.96-1.08)$ & $1.02(0.99-1.06)$ \\
\hline Former user & $344(79.1)$ & $0.97(0.87-1.08)$ & $0.97(0.91-1.03)$ \\
\hline Non-user & $7,511(81.8)$ & 1.00 & 1.00 \\
\hline Osteoporosis prophylaxis & $9,673(85.1)$ & & \\
\hline Current user & I,476 (84.7) & $1.00(0.94-1.05)$ & $1.00(0.98-1.03)$ \\
\hline Former user & $392(90.1)$ & $1.06(0.96-1.17)$ & $1.07(1.03-1.11)$ \\
\hline Non-user & $7,805(85.0)$ & 1.00 & 1.00 \\
\hline Future fall prophylaxis & $9,402(82.7)$ & & \\
\hline Current user & $\mathrm{I}, 43 \mathrm{I}(82.1)$ & $0.99(0.94-1.05)$ & $1.00(0.97-1.03)$ \\
\hline Former user & $380(87.4)$ & $1.06(0.95-1.17)$ & $1.06(1.02-1.11)$ \\
\hline Non-user & $7,591(82.7)$ & 1.00 & 1.00 \\
\hline
\end{tabular}

Notes: adjusted for age, gender, marital status, operation year, myocardial infarction, congestive heart failure, peripheral vascular disease, dementia, chronic pulmonary disease, connective tissue disease, ulcer disease, liver disease, diabetes type I and 2, hemiplegia, moderate to severe renal disease, cancer, non-steroidal anti-inflammatory drugs, corticosteroids, anticoagulants, statins, non-SSRI antidepressants, antipsychotics, and clustering by unit setting. The numbers in bold represent the total number of patients fulfilling each process-performance measure. 


\section{Sensitivity analyses}

Multiple imputation

\section{Methods}

In the multiple imputation model, we included all variables that were in the subsequent analysis model: selective serotonin reuptake inhibitors (SSRIs), age, gender, marital status, operation year, BMI, comorbidities, and other medication. Further- more, some auxiliary variables such as operation delay, fracture type, operation type, and postoperative complications were included. Imputation of BMI values was done using truncated regression creating 20 imputed datasets. After imputation, the association between SSRI use and mortality was estimated in each imputed dataset. The measures of association from each imputed dataset were combined using Rubin's rule.

Table S5 Baseline characteristics of hip fracture patients $(n=68,487)$ according to preoperative selective serotonin reuptake inhibitor (SSRI) use 2006-2016 after imputation of BMI

\begin{tabular}{|c|c|c|c|c|c|c|c|c|}
\hline \multirow[t]{3}{*}{ Variables } & \multirow{2}{*}{\multicolumn{2}{|c|}{ All patients }} & \multicolumn{6}{|l|}{ SSRI } \\
\hline & & & \multicolumn{2}{|c|}{ Non-users } & \multicolumn{2}{|c|}{ Former users } & \multicolumn{2}{|c|}{ Current users } \\
\hline & $\mathbf{n}$ & $\%$ & $\mathbf{n}$ & $\%$ & $\mathbf{n}$ & $\%$ & $\mathbf{n}$ & $\%$ \\
\hline Total & 68,487 & 100 & 52,438 & 76.6 & 2,777 & 4.0 & 13,272 & 19.4 \\
\hline Median age (years) & 83 & & 83 & & 83 & & 84 & \\
\hline \multicolumn{9}{|l|}{ Age (years) } \\
\hline $65-74$ & $|3,27|$ & 19.4 & $|0,57|$ & 20.2 & 533 & 19.2 & 2,167 & 16.3 \\
\hline $75-84$ & 26,086 & 38.1 & 19,768 & 37.7 & 1,159 & 41.7 & 5,159 & 38.9 \\
\hline$\geq 85$ & 29,130 & 42.5 & 22,099 & 42.1 & 1,085 & 39.1 & 5,946 & 44.8 \\
\hline \multicolumn{9}{|l|}{ Gender } \\
\hline Male & 19,750 & 28.8 & $|5,54|$ & 29.6 & 730 & 26.3 & 3,479 & 26.2 \\
\hline Female & 48,737 & 71.2 & 36,897 & 70.4 & 2,047 & 73.7 & 9,793 & 73.8 \\
\hline \multicolumn{9}{|l|}{ Marital status } \\
\hline Married & 20,300 & 29.6 & 16,105 & 30.7 & 842 & 30.3 & 3.353 & 25.3 \\
\hline Unmarried & 48,187 & 70.4 & 36,333 & 69.3 & 1,935 & 69.7 & 9,919 & 74.7 \\
\hline \multicolumn{9}{|l|}{ Housing } \\
\hline Own accommodation & 31,075 & 45.4 & 25,537 & 48.7 & 1,126 & 40.5 & 4,412 & 33.2 \\
\hline Homeless & 22 & $<0.1$ & 20 & 0.1 & 0 & 0.0 & 2 & $<0.1$ \\
\hline Residential institution & 7,105 & 10.4 & 4,213 & 8.0 & 408 & 14.7 & 2,484 & 18.7 \\
\hline Unknown & 30,285 & 44.2 & 22,668 & 43.2 & 1,243 & 44.8 & 6,374 & 48.0 \\
\hline \multicolumn{9}{|l|}{ Fracture type } \\
\hline Fracture of femoral neck & 36,341 & 53.1 & 27,854 & 53.1 & $\mathrm{I}, 45 \mathrm{I}$ & 52.3 & 7,036 & 53.0 \\
\hline Per- and subtrochanteric fracture & 32,146 & 46.9 & 24,584 & 46.9 & 1,326 & 47.7 & 6,236 & 46.9 \\
\hline \multicolumn{9}{|l|}{ Operation type } \\
\hline Alloplastic surgery & 46,859 & 68.4 & 35,843 & 68.4 & 1,902 & 68.5 & 9,114 & 68.7 \\
\hline Osteosynthesis & 21,628 & 31.6 & 16,595 & 31.6 & 875 & 31.5 & 4,158 & 31.3 \\
\hline \multicolumn{9}{|l|}{ Operation delay (hours) } \\
\hline$<24$ & $4 I, 67 \mid$ & 60.8 & 31,859 & 60.8 & $|, 72|$ & 62.0 & 8,091 & 61.0 \\
\hline $24-48$ & 12,517 & 18.3 & 9,646 & 18.4 & 461 & 16.6 & 2,410 & 18.1 \\
\hline$>48$ & 14,299 & 20.9 & 10,933 & 20.8 & 595 & 21.4 & 2,771 & 20.9 \\
\hline \multicolumn{9}{|l|}{ Operation year } \\
\hline 2006-2010 & $32,|3|$ & 46.9 & 23,822 & 45.4 & $\mathrm{I}, 342$ & 48.3 & 6,967 & 52.5 \\
\hline $2011-2016$ & 36,356 & 53.1 & 28,616 & 54.6 & $\mathrm{I}, 435$ & 51.7 & 6,305 & 47.5 \\
\hline \multicolumn{9}{|l|}{ BMI $\left(\mathbf{k g} / \mathbf{m}^{2}\right)^{\mathrm{a}}$} \\
\hline <18.5: underweight & 7,672 & 11.2 & 5,806 & II.I & 357 & 12.9 & I,509 & 11.4 \\
\hline$\geq 18.5<25$ : normal weight & 35,397 & 51.7 & 27,163 & 51.8 & $\mathrm{I}, 440$ & 51.8 & 6,794 & 51.2 \\
\hline$\geq 25$ : overweight or obese & 25,418 & 37.1 & 19,469 & 37.1 & 980 & 35.3 & 4,969 & 37.4 \\
\hline \multicolumn{9}{|l|}{ Charlson Comorbidity Index } \\
\hline Low $(0)$ & 27,283 & 39.8 & 22,505 & 42.9 & 840 & 30.3 & 3,938 & 29.7 \\
\hline Medium (I-2) & 27,787 & 40.6 & 20,365 & 38.8 & $\mathrm{I}, 244$ & 44.8 & 6,178 & 46.5 \\
\hline High (3+) & $13,4 \mid 7$ & 19.6 & 9,568 & 18.3 & 693 & 24.9 & 3,156 & 23.8 \\
\hline
\end{tabular}


Table S5 (Continued)

\begin{tabular}{|c|c|c|c|c|c|c|c|c|}
\hline \multirow[t]{3}{*}{ Variables } & \multirow{2}{*}{\multicolumn{2}{|c|}{ All patients }} & \multicolumn{6}{|l|}{ SSRI } \\
\hline & & & \multicolumn{2}{|c|}{ Non-users } & \multicolumn{2}{|c|}{ Former users } & \multicolumn{2}{|c|}{ Current users } \\
\hline & $\mathbf{n}$ & $\%$ & $\mathbf{n}$ & $\%$ & $\mathbf{n}$ & $\%$ & $\mathbf{n}$ & $\%$ \\
\hline \multicolumn{9}{|l|}{ Comorbidity } \\
\hline Myocardial infarction & 3,762 & 5.5 & 2,820 & 5.4 & $15 \mid$ & 5.4 & 791 & 6.0 \\
\hline Congestive heart failure & 6,289 & 9.2 & 4,632 & 8.8 & 291 & 10.5 & 1,366 & 10.3 \\
\hline Peripheral vascular disease & 5,511 & 8.1 & 4,060 & 7.7 & 267 & 9.6 & $\mathrm{I}, 184$ & 8.9 \\
\hline Cerebrovascular disease & 12,678 & 18.5 & 8,467 & 16.2 & 689 & 24.8 & 3,522 & 26.5 \\
\hline Dementia & 6,733 & 9.8 & 3,859 & 7.4 & 433 & 15.6 & $2,44 I$ & 19.4 \\
\hline Chronic pulmonary disease & 8,663 & 12.7 & 6,191 & 11.8 & 496 & 17.9 & 1,976 & 14.9 \\
\hline Connective tissue disease & 3,243 & 4.7 & 2,480 & 4.7 & 139 & 5.0 & 624 & 4.7 \\
\hline Ulcer disease & 3,855 & 5.6 & 2,673 & 5.1 & 224 & 8.1 & 958 & 7.2 \\
\hline Liver disease & 870 & 1.3 & 646 & 1.2 & 46 & 1.7 & 178 & 1.3 \\
\hline Diabetes type $I$ and 2 & 6,689 & 9.8 & 5,005 & 9.5 & 281 & 10.1 & 1,403 & 10.6 \\
\hline Hemiplegia & 175 & 0.3 & 111 & 0.2 & 12 & 0.4 & 52 & 0.4 \\
\hline Moderate to severe renal disease & 2,688 & 3.9 & 1,973 & 3.4 & 132 & 4.8 & 583 & 4.4 \\
\hline Cancer & 10,957 & 16.0 & 8,351 & 15.9 & 501 & 18.0 & 2,105 & 15.9 \\
\hline \multicolumn{9}{|l|}{ Other medication } \\
\hline NSAIDs & 7,681 & 11.2 & 5,869 & 11.2 & 334 & 12.0 & I,478 & II.I \\
\hline Corticosteroids & 4,158 & 6.1 & 3,068 & 5.9 & 186 & 6.7 & 904 & 6.8 \\
\hline Anticoagulants & 26,716 & 39.0 & 19,323 & 36.9 & 1,064 & 38.3 & 6,329 & 47.7 \\
\hline Statins & 13,052 & 19.1 & 9,581 & 18.3 & 505 & 19.2 & 2,966 & 22.4 \\
\hline Other antidepressants & 7,975 & 11.6 & 4,977 & 9.5 & 596 & 21.5 & 2,402 & 18.1 \\
\hline Antipsychotics & 4,992 & 7.3 & 2,899 & 5.5 & 319 & 11.5 & $\mathrm{I}, 774$ & 13.4 \\
\hline
\end{tabular}

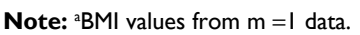

Abbreviation: NSAIDs, non-steroidal anti-inflammatory drugs.

Table S6 Incidences and HRs with $95 \% \mathrm{Cls}$ of mortality within 30 days of hip fracture surgery according to selective serotonin reuptake inhibitor (SSRI) use 2006-2016 ( $\mathrm{N}=68,487)$ after imputation of BMI

\begin{tabular}{lllll}
\hline & Events & Incidence (95\% Cl) & Unadjusted HR (95\% Cl) & Adjusted $^{\mathrm{a}}$ HR (95\% Cl) \\
\hline Current user & 1,755 & $13.2(12.7-12.8)$ & $1.35(1.28-1.43)$ & $1.16(1.10-1.22)$ \\
Former user & 338 & $12.2(11.0-12.5)$ & $1.24(1.11-1.38)$ & $1.12(1.00-1.24)$ \\
Non-user & 5,202 & $9.9(9.7-10.2)$ & 1.00 & 1.00 \\
\hline
\end{tabular}

Notes: aAdjusted for age, gender, marital status, BMI, operation year, myocardial infarction, congestive heart failure, peripheral vascular disease, dementia, chronic pulmonary disease, connective tissue disease, ulcer disease, liver disease, diabetes type I and 2, hemiplegia, moderate to severe renal disease, cancer, non-steroidal anti-inflammatory drugs, corticosteroids, anticoagulants, statins, non-SSRI antidepressants, antipsychotics, and clustering by unit setting. 
Table S7 Baseline characteristics of hip fracture patients $(n=68,487)$ according to preoperative selective serotonin reuptake inhibitor (SSRI) use 2006-2016 after changing the exposure definition

\begin{tabular}{|c|c|c|c|c|c|c|c|c|}
\hline \multirow[t]{3}{*}{ Variables } & \multirow{2}{*}{\multicolumn{2}{|c|}{ All patients }} & \multicolumn{6}{|l|}{ SSRIs } \\
\hline & & & \multicolumn{2}{|c|}{ Non-users } & \multicolumn{2}{|c|}{ Former users } & \multicolumn{2}{|c|}{ Current users } \\
\hline & $\mathbf{n}$ & $\%$ & $\mathbf{n}$ & $\%$ & $\mathbf{n}$ & $\%$ & $\mathbf{n}$ & $\%$ \\
\hline Total & 68,487 & 100 & 52,841 & 77.2 & 1,116 & 1.6 & 14,530 & 21.2 \\
\hline Median age (years) & 83 & & 83 & & 82 & & 84 & \\
\hline \multicolumn{9}{|l|}{ Age (years) } \\
\hline $65-74$ & $|3,27|$ & 19.4 & 10,620 & 20.1 & 230 & 20.6 & 2,421 & 16.6 \\
\hline $75-84$ & 26,086 & 38.1 & 19,910 & 37.7 & 487 & 43.6 & 5,689 & 39.2 \\
\hline$\geq 85$ & 29,130 & 42.5 & 22,311 & 42.2 & 399 & 35.8 & 6,420 & 44.2 \\
\hline \multicolumn{9}{|l|}{ Gender } \\
\hline Male & 19,750 & 28.8 & 15,690 & 29.7 & 274 & 24.5 & 3,786 & 26.1 \\
\hline Female & 48,737 & 71.2 & 37,151 & 70.3 & 842 & 75.5 & 10,744 & 73.9 \\
\hline \multicolumn{9}{|l|}{ Marital status } \\
\hline Married & 20,300 & 29.6 & 16,247 & 30.7 & 320 & 28.7 & 3,733 & 25.7 \\
\hline Unmarried & 48,187 & 70.4 & 36,594 & 69.3 & 796 & 71.3 & 10,797 & 74.3 \\
\hline \multicolumn{9}{|l|}{ Housing } \\
\hline Own accommodation & 31,075 & 45.4 & 25,728 & 48.7 & 414 & 37.1 & 4,933 & 33.9 \\
\hline Homeless & 22 & $<0.1$ & 17 & $<0.1$ & 3 & 0.3 & 2 & $<0.1$ \\
\hline Residential institution & 7,150 & 10.4 & 4,232 & 8.0 & 190 & 17.0 & 2,683 & 18.5 \\
\hline Unknown & 30,285 & 44.2 & 22,864 & 43.3 & 509 & 45.6 & 6,912 & 47.6 \\
\hline \multicolumn{9}{|l|}{ Fracture type } \\
\hline Fracture of femoral neck & 36,341 & 53.1 & 28.073 & 53.1 & 595 & 53.3 & 7.673 & 52.8 \\
\hline Per- and subtrochanteric fracture & 32,146 & 46.9 & 24,768 & 46.9 & 521 & 46.7 & 6,857 & 47.2 \\
\hline \multicolumn{9}{|l|}{ Operation type } \\
\hline Alloplastic surgery & 46,859 & 68.4 & 36,122 & 68.4 & 761 & 68.2 & 9,976 & 68.7 \\
\hline Osteosynthesis & 21,628 & 31.6 & 16,719 & 31.6 & 355 & 31.8 & 4,554 & 31.3 \\
\hline \multicolumn{9}{|l|}{ Operation delay (hours) } \\
\hline$<24$ & $4 I, 67 \mid$ & 60.8 & 32,090 & 60.7 & 700 & 62.7 & 8,881 & 61.1 \\
\hline $24-48$ & 12,517 & 18.3 & 9,715 & 18.4 & 196 & 17.6 & 2,606 & 17.9 \\
\hline$>48$ & 14,299 & 20.9 & 11,036 & 20.9 & 220 & 19.7 & 3,043 & 21.0 \\
\hline \multicolumn{9}{|l|}{ Operation year } \\
\hline 2006-2010 & $32,|3|$ & 46.9 & 24,061 & 45.5 & 539 & 48.3 & 7,531 & 51.8 \\
\hline $2011-2016$ & 36,356 & 53.1 & 28,780 & 54.5 & 577 & 51.7 & 6,999 & 48.2 \\
\hline \multicolumn{9}{|l|}{ BMI $\left(\mathbf{k g} / \mathbf{m}^{2}\right)$} \\
\hline$<18.5$ : underweight & 5,988 & 8.8 & 4,623 & 8.7 & 104 & 9.3 & $I, 26 \mid$ & 8.7 \\
\hline$\geq 18.5<25$ : normal weight & 31,582 & 46.1 & 24,630 & 46.6 & 492 & 44.1 & 6,460 & 44.5 \\
\hline$\geq 25$ : overweight or obese & 17,622 & 25.7 & 13,616 & 25.8 & 292 & 26.2 & $3,7 \mid 4$ & 25.5 \\
\hline Unknown & 13,295 & 19.4 & 9,972 & 18.9 & 228 & 20.4 & 3,095 & 21.3 \\
\hline \multicolumn{9}{|l|}{ Charlson Comorbidity Index } \\
\hline Low $(0)$ & 27,283 & 39.8 & 22,655 & 42.9 & 339 & 30.4 & 4,289 & 29.5 \\
\hline Medium (I-2) & 27,787 & 40.6 & 20,544 & 38.9 & 494 & 44.3 & 6,749 & 46.5 \\
\hline High (3+) & 13,417 & 19.6 & 9,642 & 18.2 & 283 & 25.3 & 3,492 & 24.0 \\
\hline \multicolumn{9}{|l|}{ Comorbidity } \\
\hline Myocardial infarction & 3,762 & 5.5 & 2,848 & 5.4 & 57 & 5.1 & 857 & 5.9 \\
\hline Congestive heart failure & 6,289 & 9.2 & 4,677 & 8.9 & 125 & 11.2 & $\mathrm{I}, 487$ & 10.2 \\
\hline Peripheral vascular disease & 5,511 & 8.1 & 4,092 & 7.7 & 112 & 10.0 & $\mathrm{I}, 307$ & 9.0 \\
\hline Cerebrovascular disease & 12,678 & 18.5 & 8,549 & 16.2 & 278 & 24.9 & 3,851 & 26.5 \\
\hline Dementia & 6,733 & 9.8 & 3,891 & 7.4 & 172 & 15.4 & 2,670 & 18.4 \\
\hline Chronic pulmonary disease & 8,663 & 12.7 & 6,229 & 11.8 & 187 & 16.8 & 2,247 & 15.5 \\
\hline Connective tissue disease & 3,243 & 4.7 & 2,495 & 4.7 & 60 & 5.4 & 688 & 4.7 \\
\hline Ulcer disease & 3,855 & 5.6 & 2,693 & 5.1 & 81 & 7.3 & $|, 08|$ & 7.4 \\
\hline Liver disease & 870 & 1.3 & 647 & 1.2 & 24 & 2.2 & 199 & $\mathrm{I} .4$ \\
\hline Diabetes type $I$ and 2 & 6,689 & 9.8 & 5,041 & 9.5 & $|3|$ & 11.7 & 1,517 & 10.4 \\
\hline Hemiplegia & 175 & 0.3 & 112 & 0.2 & 3 & 0.3 & 60 & 0.4 \\
\hline Moderate to severe renal disease & 2,688 & 3.9 & 1,995 & 3.8 & 54 & 4.8 & 639 & 4.4 \\
\hline Cancer & 10,957 & 16.0 & 8,440 & 16.0 & 175 & 15.7 & 2,342 & 16.1 \\
\hline
\end{tabular}


Table S7 (Continued)

\begin{tabular}{|c|c|c|c|c|c|c|c|c|}
\hline \multirow[t]{3}{*}{ Variables } & \multirow{2}{*}{\multicolumn{2}{|c|}{ All patients }} & \multicolumn{6}{|l|}{ SSRIs } \\
\hline & & & \multicolumn{2}{|c|}{ Non-users } & \multicolumn{2}{|c|}{ Former users } & \multicolumn{2}{|c|}{ Current users } \\
\hline & $\mathbf{n}$ & $\%$ & n & $\%$ & n & $\%$ & $\mathbf{n}$ & $\%$ \\
\hline \multicolumn{9}{|l|}{ Other medication } \\
\hline NSAIDs & 7,681 & 11.2 & 5,926 & 11.2 & 128 & 11.5 & 1,627 & 11.2 \\
\hline Corticosteroids & 4,158 & 6.1 & 3,100 & 5.9 & 86 & 7.7 & 972 & 6.7 \\
\hline Anticoagulants & 26,716 & 39.0 & 19,520 & 36.9 & 425 & 38.1 & 6,771 & 46.6 \\
\hline Statins & 13,052 & 19.1 & 9,698 & 18.4 & 182 & 16.3 & 3,172 & 21.8 \\
\hline Other antidepressants & 7,975 & 11.6 & 4,905 & 9.3 & 372 & 33.3 & 2,698 & 18.6 \\
\hline Antipsychotics & 4,992 & 7.3 & 2,897 & 5.5 & 165 & 14.8 & 1,930 & 13.3 \\
\hline
\end{tabular}

Abbreviation: NSAIDs, non-steroidal anti-inflammatory drugs.

Table S8 Incidences and HRs with $95 \%$ Cls of mortality within 30 days of hip fracture surgery according to selective serotonin

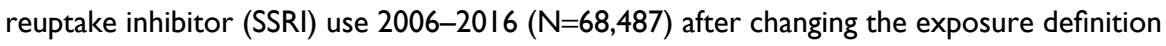

\begin{tabular}{|c|c|c|c|c|}
\hline & Events & Incidence $(95 \% \mathrm{CI})$ & Unadjusted HR (95\% CI) & Adjusted $^{\mathrm{a}}$ HR (95\% CI) \\
\hline Current user & $\mathrm{I}, 907$ & I3.I (12.6-13.7) & $1.34(1.27-1.4 I)$ & $1.16(1.10-1.21)$ \\
\hline Former user & 137 & $12.3(10.5-14.4)$ & I.25 (I.05-I.48) & I. I 2 (0.97-I.30) \\
\hline Non-user & 5,251 & $9.9(9.7-10.2)$ & 1.00 & 1.00 \\
\hline
\end{tabular}

Notes: aAjusted for age, gender, marital status, operation year, myocardial infarction, congestive heart failure, peripheral vascular disease, dementia, chronic pulmonary disease, connective tissue disease, ulcer disease, liver disease, diabetes type I and 2, hemiplegia, moderate to severe renal disease, cancer, non-steroidal anti-inflammatory drugs, corticosteroids, anticoagulants, statins, non-SSRI antidepressants, antipsychotics, and clustering by unit setting.

Clinical Epidemiology

\section{Publish your work in this journal}

Clinical Epidemiology is an international, peer-reviewed, open access, online journal focusing on disease and drug epidemiology, identification of risk factors and screening procedures to develop optimal preventative initiatives and programs. Specific topics include: diagnosis, prognosis, treatment, screening, prevention, risk factor modification,

\section{Dovepress}

systematic reviews, risk and safety of medical interventions, epidemiology and biostatistical methods, and evaluation of guidelines, translational medicine, health policies and economic evaluations. The manuscript management system is completely online and includes a very quick and fair peer-review system, which is all easy to use. 